\title{
The Legal Efforts on Marine Culture Development in Pacitan, 1999-2015
}

\author{
Heru Arif Pianto \\ Sekolah Tinggi Keguruan dan Ilmu Pendidikan PGRI Pacitan \\ Indonesian Historian Association, East Java Branch \\ Corresponding Author: ariefheru84@gmail.com
}

\begin{abstract}
Beach is one of the most famous tourism areas in Pacitan. Beaches in Pacitan have special features compared to other beaches. The beautiful nature is able to attract tourists to come, visit and enjoy it. Therefore, the beaches in Pacitan have a lot of possibilities to be a tourism area of marine culture.

Received: This article is a historical research. The method used in this study was a historical research method, consisting of four steps, heuristics, criticism, interpretation and historiography. The results of this study indicate that the beaches in the Pacitan region have special attraction for tourists to visit.

Thus, to be a tourism area of marine culture, Pacitan requires a better management. Based on research conducted so far, the beaches in Pacitan have not been managed optimally, due to a lack of facilities, and low human resources as managers. In short, it is the responsibility of communities, private parties and local governments to maximize the quality of management of coastal tourism around Pacitan, and their cooperation is need. Therefore, the beaches can be a tourist area of marine culture that can grow rapidly in Pacitan region.
\end{abstract} 4 April 2017

Accepted: 18 May 2017

Keywords: Marine culture; Beach tourism; Development efforts; Pacitan.

\section{Introduction}

Indonesia is a country that is rich in natural beauty, flora and fauna and it is also a multicultural community. These elements can contribute large foreign exchange to the tourism aspect. In general, tourism is seen as a sector that may encourage and enhance development activities, open employment opportunities, as well as potential for increase the local revenue. All of these that can be achieved if the tourism is able to be managed maximally. Nowadays, business in the tourism sector is not an easy thing, as there are many obstacles and constraints due to the emergence of multidimensional crisis. This provides a large effect on the quantity of domestic and foreign tourists visit in enjoying the natural beauty and culture owned by Indonesia (Department of Culture, Tourism, Youth, and Sports Affairs of Pacitan, 2008). 
In order to enter the current globalization era, the role of the tourism industry must be supported by qualified and professional human resources due to the increasingly tight competition of the tourism world. In addition, as Indonesia is passed by the equator, it has a climate that gives rise to a variety of flora and fauna that can attract the tourists to visit Indonesia. Other factors supporting the geographical conditions of Indonesia in the form of tropical forests, mountains, beaches, and also the oceans and cultural diversity are the potential capital base to become a famous tourist destination. Many areas supported by the beauty of nature in Indonesia have important role in the tourism, to be managed well, to increase own-source revenue.

Not apart from that, Pacitan district is also supported by adequate natural resources that play an active role to maximize the management of tourism areas. Pacitan district has 12 subdistricts namely, Donorojo, Punung, Pringkuku, Pacitan, Kebonagung, Tulakan, Ngadirojo, Sudimoro, Arjosari, Tegalombo, Nawangan and Bandar. Each district has a main tourist attraction that may attract tourists. Various attractions in the area of Pacitan District are dominated by marine tourism; therefore, the maritime potential in Pacitan is highly quality. In addition, there is an international standard coastal tourism in Pacitan, Teleng Ria Beach. Moreover, there is still much marine tourism that has not been developed well, which actually has its own uniqueness (Department of Culture, Tourism, Youth, and Sports Affairs of Pacitan, 2008).

The development of southern Java region, where the Pacitan District is located, is in the form of procurement of adequate road infrastructure that may facilitate the flow of transportation from the region of Central Java, East Java and Special Region of Yogyakarta. Of course, this is also supported by the travel agencies of each region. A good management of tourist attractions is performed by local government through the Department of Culture, Tourism, Youth and Sports Affairs, as well as the supports from the communities that increasingly make Pacitan worth visiting as tourism areas.

\section{Method}

This article use historical research on how to reconstruct the past through the process of testing and critical analysis on the recording and relics of the past (Gottschalk, 1983:18-32). Generally, historical research has four steps that included; heuristics (source collection), criticism (source verification), interpretation and presentation stage (Rochmat, 2009:147-151). Historical sources used are primary and secondary sources in the form of books, magazines as well as prints or reports.

The first research method conducted was heuristic. Heuristic is the ability to find and collect the resources needed in the writing of history. The principle that must be performed is the primary source search stage. In this study, the writer collected the source of activity documentation archive as well as conducted the interviews.

The second step was to criticize the source. In this step, it was conducted the assessment, testing and selection of traces or sources that had been collected. This criticism stage could be distinguished into two types namely, internal criticism and external criticism (Widja, 1998:21-22). In this study, the external criticism was 
conducted to find out the authenticity of the historical sources that had been successfully collected, while internal criticism was used to assess the credibility of the source.

The third step was interpretation. Those various sources had not been meaningful if the interpretation had not been conducted, that including analysis and synthesis (Kuntowijoyo, 2009:100-102). Then the sources that had been passed in the external and internal criticism were synthesized. In this stage, the meaning and relationship of facts that were causal or interrelated as well as chronological are able to be determined. The method of historical interpretation was often directed to the philosopher's view, so that historians might find possible solution in facing the historical problems.

The last step was historical historiography. This stage was the final stage of writing or reconstructing the past events in the form of historical stories poured into writing (Kartodirdjo, 1982:60-61). In this stage, certain skills to maintain the standard of story quality such as serialization, chronology, causality and imagination were required (Widya, 1998:24). Writing the results of historical research might provide a clear picture of the research process from beginning to end. Therefore, it could be found whether the research was conducted in accordance with the procedure or not, and to what extent the validity of the sources was obtained. In addition, we could see whether the work of the historians concerned was interesting or not, because in the writing, the historian had to be also be smart in processing and composing interesting sentences without eliminating the quality of historical story written. Here, the writer presented the paper in the form of historical stories that were written chronologically from theme or topic that is clear and easy to understand.

\section{Results and Discussion \\ Geographical Condition}

Pacitan is an area located in the southwest of East Java Province which is directly adjacent to Central Java Province. The geographical boundaries of Pacitan District are as follows.

1) Ponorogo District (East Java) and Wonogiri District (Central Java) in the north.

2) Trenggalek District (East Java) in the east.

3) Indian Ocean in the south.

4) Wonogiri District Ocean in the west.

Geographically, Pacitan District lies between $7.55^{\circ}-8.17^{\circ} \mathrm{SL}$ and $110.55^{\circ}-111.25^{\circ} \mathrm{EL}$ (The Government of Pacitan, 2011:4). The area of Pacitan District is around 1.389,87 $\mathrm{km}^{2}$ with the area of paddy field by $130.15 \mathrm{Km}^{2}$ or around 9.36 percent and the total dry land is $1.259,72 \mathrm{~km}^{2}$ or around 90.64 percent. Most of the wetlands are rainfed rice field by 51.53 percent and most of the dry land is for Woody plants by 35.89 percent (The Government of Pacitan, 2011:4).

Pacitan district is formed with the region consisting of twelve districts namely: Kebonagung, Pacitan, Pringkuku, Punung, Donorojo, Arjosari, Tegalombo, Nawangan, Bandar, Tulakan, Ngadirojo and Sudimoro. From that many subdistricts, 
they are divided into 171 villages/urban villages (The Government of Pacitan, 2006:4). Of the 12 subdistricts, they have their own geographical condition that are relatively similar in the mountain area. Most of them are located in rural areas that in fact have a simple life. The communities also emphasize more on the processing of natural or agricultural products. This happens because of the environmental factors that is indeed supporting for the development and processing of agricultural land as the main livelihood of the population. Pacitan is a southern coastal area of Java island surrounded by seas and hills. This condition causes some areas of Pacitan are difficult to reach by large vehicles. In fact, there are some tourist attractions that are not still able to reach by large vehicles; consequently, many tourists are forced to use motorcycle.

When viewed from the physical condition of the region, the topography aspect of Pacitan district shows the landscape with various slopes as follows:

1) The slope of $0-2 \%$ that covers $4.36 \%$ of the area is in the form of seashore

2) The slope of $2-15 \%$ that covers $6.60 \%$ of the area is for agriculture and the area is considered for soil and water preservation.

3) The slope of 15 - $45 \%$ that covers $25.87 \%$ of the area is used for annual crops.

4) The slope of $40 \%$ above that covers $63.17 \%$ of the area is functioned as a land and water buffer zone and serves to maintain the balance of ecosystems in Pacitan district.

Pacitan District is also a tourist area that has a fairly high level. In addition to the areas that have a number of quite long beach, Pacitan District also has a very interesting tourism potential that includes many caves, beautiful and fascinating natural environment for tourists to visit and enjoy. The famous tourist objects in Pacitan district have a very interesting natural view to visit. This is supported by the geographical condition of Pacitan district located on the south coast of Java Island. The tourist objects include the beach and cave. Pacitan has many good sized beaches with small and medium scale, and almost every district in Pacitan has a beach as a tourist attraction of the community that want to prove the beauty of natural view of Pacitan region. Among the beaches that have a very beautiful natural view are teleng ria beach in Pacitan subdistrict, klayar beach in Donorojo subdistrict, watu karung beach in pringkuku subdistrict, and wawaran beach in kebonagung subdistrict. These beaches have the beauty of nature potential and also contain millions natural wealth. The local communities around the beaches are much benefited with the fresh fish found in the seas in Pacitan ((The Government of Pacitan, 2011:192).

Tourist attraction in the form of cave is also commonly found in Pacitan. Some caves or stone tunnels that is indeed formed in Pacitan are gong cave, tabuhan cave, putri cave and so forth. All the caves are visited by many tourists both domestic and foreign tourists every day. This brings an impact to Pacitan, in addition to the name of Pacitan that can be known throughout the region, it also increases the regional cash income. Indirectly, these tourism areas also contribute in improving the living standards of the Pacitan community. 
The availability of supportive natural resources encourages the community to utilize the available resources. Many Pacitan communities use the rocks as a commodity of stone craftsmen. They make the rocks into agate, souvenirs and other objects that have a relatively high selling price. In addition, there are people who work in the pottery business that is quite famous. They are able to run the business due to the support of available natural resources (The Government of Pacitan, 2011:304-310).

The beauty of Pacitan's natural resources attracts many visitors from both inside and outside of the city. Tourist attraction in Pacitan has its own natural beauty so it is not surprising if every day Pacitan is visited by many domestic and foreign tourists. The tourist visit, in fact is able to provide a positive impact for the community around the tourist attraction. Many of them run food sales activities, including the services provided to the visitors. It is very helpful to the community in terms of economic growth.

\section{The Development of Beach Areas as Tourist Destinations in Pacitan}

Beaches in Pacitan have a natural beauty and white sand. Geographically, the coastal tourism is located in several villages. The average distance from district is as far as 45 $\mathrm{km}$ and $20 \mathrm{~km}$ from the subdistrict. To go to some beaches, people have to pass the switchback and winding road that are decorated with beautiful scenery including a variety of stunning natural view with a row of towering hills, as well as small caves where people can see the stalactites and stalagmites from the side of the road. Therefore, although the road is fairly challenging but the tourists who go to the beach do not feel tired and bored.

In addition, the beaches in Pacitan have a special feature compared to other beaches existing outside the Pacitan area, called as sea fountain between the rock gap and the tidal wave. The condition of this beach is still very natural, it can be seen from the clean and fine sand and the sparkling blue rolling wave, so this beach is worth mentioning as the paradise of Pacitan. The atmosphere of the beach itself is still very natural, the seashore is decorated with coconut trees and huts/shelter roofed with dried leaves, reefs on the tidal areas are also still maintained naturally, in addition to the wave blast that emit blue color that marks the sea water that has not been polluted. Tourists can also search for the coral reefs to find shells (Mollusca), and starfish (Echinodermata). In addition, along the rocks there is also snail as well as seaweed that grow around the rocks. The beauty of beaches in Pacitan is not up there, as the tourists can see directly local people climb coconut trees to take air deresan (raw materials for the brown sugar production) or have the coconut water served directly by the local people while enjoying the natural exotic beach in Pacitan.

With such beauty, it is not surprising that many domestic and foreign tourists want to prove the beauty of the beaches in the Pacitan region. Based on statistical data for the last 6 years, the number of visitors of coastal tourism in Pacitan has increased. Moreover, the highest retribution value was in 2013 (see detail in Table 1). 
Table 1. Tourist Visit Rate in Pacitan Beach Region

\begin{tabular}{ccc}
\hline No & Year & Total Visitor \\
\hline 1 & 2009 & 5510 \\
2 & 2010 & 11836 \\
3 & 2011 & 40679 \\
4 & 2012 & 45891 \\
5 & 2013 & 50233 \\
\hline
\end{tabular}

Source: Dinas Kebudayaan, Pariwisata, dan Olahraga Kabupaten Pacitan 2008.

Therefore, we can draw an underlying cause that the beaches in Pacitan region are the pride of Pacitan district community, the exotic beaches with white sand. In addition to the natural resources, the tourism must be supported by reliable human resources as the beach has great potential to be used as a marine tourism as well as maritime pioneering beach in Pacitan. Pacitan area is surrounded by a vast ocean, so it is very suitable for the development of marine culture that has been untouched at all. Therefore, it requires support and cooperation from all parties, both government and community altogether to process the available natural resources for the joint prosperity of life.

In the present, it is time to optimize the utilization of natural resources. This is not easy, but it must always be prioritized, especially by local governments to manage the coastal tourism into a beach with a well-established marine culture, if necessary they are made as an international trade center with the construction of a large port. It is indeed a dream, but a dream that must be realized together. So far the vast oceans of Pacitan have not been touched by professional human resources. The sea is only used by traditional fishermen. The marketing of sea products is also less than the maximum. This should be taken immediately for the sake of better life sustainability, especially for those whose livelihood is fishermen.

If it has been analyzed based on the quantity of tourists who come to the beaches in Pacitan region, this has proven that the maritime beach potential is excellent and very supportive to be developed. The beauty of the sea's natural view so far is able to attract tourists to come and see. Therefore, what is left depends on how the management of the beach to follow up this matter to progress and attract the interest of tourists that increase every year. Of course, facilities and infrastructure should also be considered, ranging from road infrastructure, as well as other supporting facilities.

\section{Advantages and Disadvantages of Beach Tourism in Pacitan}

\section{Advantages}

As already described above, the coastal tourism in Pacitan has more advantages compared to other beaches, especially its beauty of nature. Diversity of Tourist Attraction of the character and state of coastal tourism is different from other beaches located outside Pacitan, in other words beaches in Pacitan has distinctive characters that will not be owned by other beaches. The typical advantages are: these beaches 
generally have seashore with very long white sand; the natural whistling sea fountain between the reef gaps every now and then; various evergreen plants decorate along the shore; various biotic life (clam shells, sea snails, sea slugs, and of course the diversity of marine fishes); the clear, huge, sparkling blue wave; there are typical and natural huts/shelter; the reefs are fascinating and still pristine; towering exotic hills.

In addition, the benefit of the coastal tourism is the accessible road to the beach. Pacitan is a vast area, with the good asphalted road condition (even hotmix). The road condition between the object locations itself that has been hardened with asphalt is relatively good already. Moreover, the tourists will be presented with exotic scenery along the winding road to the tourism area, which are: the natural towering hills; caves on the side of the road to the location of objects with visible stalactites and stalactites.

Another key factor is the enthereforeiasm of the people. Local people tend to preserve the natural view of the Beach and culture flourished in their area as well so that the potential of the location of Coastal Tourism will be more preserved, wellmaintained. This also applies to the developing culture in their area. The concern of the people around the Coastal Tourism for the comfort of the tourists who visit it can be categorized as one supporting factors of the potential beach in Pacitan.

\section{Disadvantages}

Although the coastal tourism in Pacitan has many advantages, there are some disadvantages of this tourist attraction. The large number of tourist attractions in Pacitan District is currently not counterbalanced with the maximum development effort. Most of the tourism attractions in Pacitan are still undeveloped, or under development. While most tourist attractions in the Pacitan District are also classified as new object types and highly potential to be developed compared to tourist attractions of other disadvantaged areas. It can be seen from the lack of facilities and infrastructure in a number of tourist attractions despite some facilities and infrastructure are available in some tourist attractions, but still lacking in the number and its maintenance. As mentioned above, the management of the coastal tourism has not fully realized yet. There are many shortfalls and weaknesses that still remain. Weaknesses which need to be considered in the Coastal Tourism areas in Pacitan are:

1) Unavailability of lodging facilities for tourists

In general, the Coastal Tourism in Pacitan has not accommodated the lodging in the form of hotels, however few lodgings in the form of homestays managed by the local community are available. Nevertheless, the problem is that they have not been maximally managed. It can be seen by the lack of facilities and services in those homestays. As such, the tourists who want to stay in Pacitan should look for other lodgings around the city, for the complete facilities and better comfort level. Actually, this is also a great opportunity for local people to establish a hospitality business with adequate facilities. So the tourists will enjoy the beauty of the beach to the fullest even at night and breathe the cold and fresh air in klayar beach without thinking about looking for a resort far from the tourist sites. For those who can read this situation, it may also an 
opportunity to provide employment as well. The local people can also be the tour guides. It is an impact and a good opportunity which should be utilized in the best way.

2) Tourism Information center (TIC)

TIC itself still does not exist until this very moment. This is because the lack of attention both from the local government and the surrounding community, with this case, the tourists will find it difficult to get information about everything in the Coastal Tourism, as a result, the tourists will be less comfortable and satisfied. It should be a big task for the local government to address and therefore finding the right solution for the development and welfare of Pacitan community.

3) Lighting

The existing lighting at the Coastal Tourism location in Pacitan is far from the standard. For example, the condition in the coastal tourism location is pitch black at night, it is impossible for tourists to enjoy the charm of Coastal Tourism at night. In addition, the lighting on the road sides is also not available. This is a major problem to be solved. Tourists during this time can only visit in the morning and afternoon, and only few tourists at night. It is because of the absence of lighting both on the access road and on the access to tourist attractions.

4) Unavailability of adequate restaurants

In reality, this good tourist attraction has not provided adequate restaurant. Even if they are present, they are merely a traditional-scale food stalls serving a limited food product. This condition also makes it difficult for the tourists to enjoy this wonderful beauty of the nature for quite a long time. They have to find restaurant that is quite far from the tourist sites. Up to now, the one who enjoys the food stalls with a few menu and limited number are the local community only.

Therefore, many tourists who are familiar with this condition of coastal areas in Pacitan often bring foods from home so they can enjoy their meal while witnessing the beauty of the nature. Imagine how perfect it is if they can visit the tourist attraction without bothering to bring foods, as it is available around the beach and they can enjoy the beauty of the nature at it utmost while enjoying the various typical dishes of Pacitan including the delicious and nutritious seafood products.

5) Limited human resources

Internal human resources of tourism and the management of tourist attraction have not met the qualifications yet, such as the level of education, class or rank, as well as special skills. The human resources provided have to master marine science and natural science so as to explain to the tourists at their best. In addition, they have to speak foreign language since lots of foreign tourists visit and need information about the beauty of this nature who are, of course, speak in foreign language. 
In addition to the aforementioned, there are also several other disadvantages of klayar beach. However, the disadvantages lie mostly on the facilitation and infrastructure. It is very unfortunate given the stunning nature is not balanced with adequate facilities so it is unable to increase the tourist visits. The more tourists who visit, the more positive impacts are gained including by the local government. Because the tourists visit can increase the Budget for Regional Income as well. Reading this opportunity, local government should immediately counterbalance the facilities of this tourist attraction in order to increase local government revenue budget.

Furthermore, the local government through the department of tourism should be able to recruit professionals who are assigned in klayar beach. Briefing, guidance and training should be given as often as possible to improve their professionalism in managing the coastal and marine tourism. Even though it takes a long process as well as large capital, the local government could take it into consideration by all means in order to improve the quality and maximize these marine tourist attractions. In addition to the local government, certainly there should be a support from the community and all parties, for the sake of the common interests and the improvement of living standards.

\section{Development Strategy}

There should be some kind of management strategy and development for tourist attraction to attract the tourists. Similarly applies for the coastal tourism in Pacitan. In developing the Coastal Tourism and for the success of its development, local government must pay attention to several important factors which can promote the successfulness, therefore the development strategy to achieve the vision and mission, as follows:

First, developing tourism objects and attractions (including nature tourism as well as arts and culture) by improving the facilities and infrastructures together with the quality and quantified tourist attractions which are more interesting and giveing a distinctive charm for the tourists. In this case, the Coastal tourism in Pacitan presents a tourist attraction of natural, white sand, long seashore and also the uniqueness of the natural whistling sea fountain between the reef gaps. All kinds of natural resources are managed in such a way to leave a good impression to the visitors, expecting that once they come, they want to feel and enjoy the beauty of the nature someday with their loved ones even with relatives, friends and the people around them.

Second, establishing cooperation between private parties and local community in terms of developing tourism facilities and businesses around the Coastal Tourism area. Development of this beach is impossible to be performed solely by the local government. To promote and facilitate the development, there must be cooperation from parties involving the local community as well as private parties who have interests. Therefore, it is expected that the development of the tourism attraction is able to be conducted well. 
Third, promotion and marketing of Coastal Tourism from various segments of local, regional, national and international market using a variety of optimal promotion and service means. A good promotion should be performed since today making promotions are easier by utilizing the advanced science and technology. Promotion via social media will be able to provide accessibility for information in regional, national and even international.

Fourth, developing the local art and culture as a form of tourism attraction preservation and upholding the cultural wealth of local of customs and values and at the same time as a filter against the infiltration of bad or inappropriate cultural effects that may be unsuitable for the eastern culture. In addition to the surrounding attractive beauty of the nature, support is needed from the cultural wealth of the community in order to attract the tourists. Tourists do not only come to enjoy the charm of nature alone, but they need to be entertained by some local cultures of those many cultures.

Coastal Tourism is an original beach natural view. Efforts to develop the existing potential of Coastal Tourism in Pacitan can be held by the addition and improvement of facilities, infrastructures and the natural conservation of the tourist attractions. The development should be performed continuously so it can provide competitiveness with tourist destinations in other areas. The development refers to two factors i.e. economic factors and socio-cultural factors. The economic factor itself is performed by the addition and improving of facilities, infrastructures, which include: entrance gate of the Coastal Tourism, viewing post, places of worship, toileting facilities, food stalls, tourism information center (TIC), and security post. Development on the economic factors is expected to support competitiveness and at the same time can increase the own-source revenue. Therefore, the living standard of Pacitan community and local people around the Coastal Tourism will increase generally.

For socio-cultural factors, its development focuses on social stability, culture, politics, and national security. So, Coastal Tourism should be able to improve the image of tourism in Pacitan District, as well as the image of national tourism in general as a safe and comfortable destination for both domestic and foreign tourists. It must be really well-managed, so that the visitors will significantly increase in number every year. Moreover, the increase in visitors will also bring good impact and is a breath of fresh air for the local governments.

\section{Obstacles Encountered in the Development of Coastal Tourism in Pacitan}

Every management of the tourist attraction in every area absolutely meets some obstacles more or less. This is indeed not a big problem yet it is a natural thing. Due to the arising problems, the management should always try to do self-correcting and rearrangement of the management strategies to improve the conditions and situations to attract the tourists to visit.

Likewise, several obstacles and problems that may have become homework for managers of the development of beaches in Pacitan region are also found. Various problems that arise for the management of tourist attraction to solve also get some 
input and criticism from the local community. It does not mean that this criticism is to haunt the manager, instead the criticism is to build as well as the serve as a trigger for the managers to improve their management professionalism.

Actually, the cases that occur in the management of tourist attraction in klayar beach bring a positive impact for the managers. The positive impacts are: First, the community becomes more critical in guarding every policy set by the local government, especially by District Department of Tourism Youth and Sports Affairs of Pacitan, so that it can be said that the community has participated actively in determining the direction of regional development, notably the development through the stage of tourist attraction development. Second, the government obtains input from the community, so that all policies set can accommodate all the aspirations of the community especially the people surround the tourism attraction. Third, with many inputs from the community, an evaluation can be created for the local government regarding its performance so that it can conduct procedural improvements and management arrangements. Fourth, with the conditions by many inputs from the public, a more professional management, the awareness from the public, private and local governments altogether in undertaking the maximum development are required.

Particularly in the development of the klayar beach in practice, several obstacles are still encountered. These existing obstacles are the tasks for local governments to find the right solution. Generally, the obstacles faced by the manager in developing this coastal tourism are below.

1) Limited development fund

With the limited budget fund from the local government, especially for the development of tourist attraction in klayar beach results in the lack of conducting guidance to the community around the location of tourist attraction in klayar beach and less maximum development of tourism attraction. It proves by the less optimal development of facilities and promotion and marketing. Therefore, klayar beach may be less well-known by the public widely. In addition, the investment to the tourist attraction management by the private parties is still lacking.

2) Limitations of facilities and infrastructure

Coastal tourism area in Pacitan during this time in terms of the procurement of facilities and infrastructure is said to be very minimal. It certainly affects the interest of tourists or visitors. Good facilities and infrastructures will automatically attract the tourists to visit because they can enjoy the beauty of the attractions as well as the variety of satisfactory facilities.

3) Limited human resources on science of tourism

Communities in the coastal area today has very minimal information so it will give impacts on the lack of knowledge of the scope of tourism science. This condition results in the lack of awareness of the surrounding environment. So, the natural environment in coastal area of klayar will gradually lose its original characteristic. If it happens continuously, then the charm of coastal tourism will fade and even lost so that the tourists will no longer want to visit it. 
4) Low accessibility

So far, the accessibility to the coastal tourism area is still very low. It is proved by the minimum means of transportation towards this tourist attraction. The unavailability of designated means of transportation will also greatly affect the graph of visitor rate. In addition, the roads leading to the tourist areas are still insufficient. Local government should, through the Department of Tourism of Youth and Sports Affairs, be quickly address this inadequate accessibility issues.

5) Low awareness of tourists on the environment

Admitted or not, at this moment tourists who visit the coastal tourism area are lack in environmental awareness. They should maintain environmental conditions of the coastal areas. Most tourists are not really care at all to the environment; the evidence is that there is still a lot of garbage littering around the beach. In addition, local cultures must also be preserved. Although many visitors are the foreign tourists, it does not mean that the local cultural conditions around the beach should follow it, definitely no. The ancient culture must be preserved as the identity of the nation.

The aforementioned are some of the obstacles encountered by the management of coastal tourism in Pacitan region that still lack in its management. These obstacles must be solved for the future of the tourist attraction that must also be improved both in the management and the number of the visitors. There should be cooperation from several parties from the public, the private parties and the local government.

\section{Conclusions}

Pacitan is an area with potential coastal tourism to be developed. In addition, there is a local cultural event which is very interesting and able to attract the attention of the people as well as domestic and foreign tourists. Its cultures or local ritual such as ceprotan is very attractive. Therefore, it requires the efforts to develop and improve the facilities and infrastructure in coastal tourism involving the participation of local communities, government and private parties.

The development of this tourism attraction is expected to increase the interest of both domestic and foreign tourists to visit this coastal tourism area. It is related to the addition of infrastructure and business facilities in the marketing of coastal tourism products. Regarding human resources, the local community has less efforts in developing these tourist attractions so that the role from all parties are very crucial both from the government, private and local communities.

In the development efforts of the coastal tourism until now, some influential obstacles and problems still come across. Those obstacles include lack of facilities and infrastructure, minimum budget funds from local governments especially from the Department of Tourism, Youth and Sports Affairs, and low Human Resources. Moreover, one factor that is significantly important is the low awareness of the tourists 
to the environment, as well as from the accessibility factor that has not been maximized.

Therefore, the government in this case represented by the Department of Tourism, Youth and Sports Affairs needs to make efforts in the addition and improvement in terms of facilities and infrastructure. Facilities and infrastructure are very important in attracting both domestic and foreign tourists. In addition, there is a good relationship or cooperation between the government, the private sector and the local community with high consistency in order to improve the professionalism of the management of coastal tourism of klayar beach. It is indeed to increase the number of tourist visit rate.

Furthermore, the marketing strategy of the coastal management plays an important role. With an attractive promotion, it will affect the interest of tourists visit. How the management deals with a good management and good marketing becomes certainly one key factor for the success of many parties.

With the development and a good management, surely the main purpose of establishing coastal tourism in Pacitan region as a maritime pioneering beach will be realized accordingly. It is the time for Pacitan to be able to maximize its geographical maritime area. To start a thing is indeed not as easy as falling off a log but it needs struggle and hard work from all parties. If it has been successfully established, the marine culture will be growing easily, it is expected that in the future, Pacitan can maximize the management of its sea products, salt factory establishment, and even the port development as a means for the international trade route. It is not merely a dream but it is a common task to manifest Pacitan as a well-established maritime area and its prosperous community by maximizing the wealth of the natural resources in the form of vast ocean.

\section{References}

BPS Kabupaten Pacitan (2011). Pacitan dalam Angka. Pacitan: BPS \& Pemerintah Kabupaten Pacitan.

Dinas Kebudayaan, Pariwisata, dan Olahraga Kabupaten Pacitan (2008). Buku Pedoman Wisata. Pacitan: Dinas Kebudayaan, Pariwisata, dan Olahraga Kabupaten Pacitan.

Gottschalk, Louis (1983). Mengerti Sejarah, translated by Nugroho Noto Susanto. Jakarta: Penerbit Universitas Indonesia.

Kartodirdjo, Sartono (1982). Pemikiran dan Perkembangan Historiografi Indonesia: Sebuah alternatif. Jakarta: Gramedia.

Kuntowijoyo (2009). Pengantar Ilmu Sejarah. Yogyakarta: Bentang.

Pemerintah Kabupaten Pacitan (2006). Hasil-hasil Pelaksanaan Pembangunan Kabupaten Pacitan Tahun 2005. Pacitan: Badan Perencanaan Pembangunan Daerah Kabupaten Pacitan.

Rochmat, Saefur (2009). Ilmu Sejarah dalam Perspektif Ilmu Sosial. Jakarta: Graha Ilmu. Widja, I.G. (1998). Pengantar Ilmu Sejarah: Sejarah dalam Perspektif Pendidikan. Semarang: Satya Wacana University Press. 